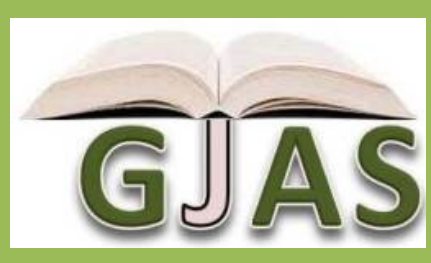

\title{
Restructuring the Agricultural Extension Service for Effective Agricultural Transformation Agenda in Nigeria
}

\author{
Obiora C. J. ${ }^{1 *}$ and Emodi A. I. ${ }^{2}$
}

${ }^{1}$ Department of Agricultural Extension, University of Nigeria, Nsukka.

${ }^{2}$ Department of Agricultural Economics and Extension, University of Port Harcourt.

\section{ARTICLE INFO}

Article No.: 061013660

DOI: 10.15580/GJAS.2013.6.061013660

Submitted: $10 / 06 / 2013$

Accepted: $22 / 06 / 2013$

Published: 29/06/2013

${ }^{*}$ Corresponding Author

Obiora C. J.

E-mail: chyjoy_obiora@yahoo.com Phone: 07035386888

\section{Keywords:}

Agriculture, agricultural extension, agricultural transformation agenda, restructuring, Nigeria

\section{ABSTRACT}

The Agricultural Transformation Agenda is all about enhancing capacity for agricultural commodity value chains leading to industrialization and employment creation, food security, infrastructure investments, private sector leadership, supportive fiscal policies and accessible market information systems to the farmers. Poor funding and absence of a well-defined agricultural extension policy among others will constitute a challenge for extension as she delivers in the transformation agenda. True commitment by the government to the newly established Federal Department of Agricultural Extension (FDAE) and proper funding of the Nigerian extension service could be employed as strategies for restructuring extension service in the on-going ATA. For a true and sustainable agricultural transformation in Nigeria, the following recommendations are made: (1) the Federal Government must be honest with the transformation agenda by being supportive and giving the newly established Federal Department of Agricultural Extension (FDAE) free hand to oversee, monitor and provide the leadership needed for an efficient and effective agricultural extension and advisory service delivery in Nigeria; (2) relevant bodies should review the agricultural extension policies within the subsisting agricultural policies and recommend appropriate policies that will ensure the effective participation of all stakeholders in a stable policy environment. 


\section{INTRODUCTION}

Agriculture is an important sector of the Nigerian economy with high potentials for employment generation, food security and poverty reduction. Agricultural sector in the 1960s provided the main source of employment, income and foreign exchange earnings for Nigeria. This was due to focused regional policies based on commodity comparative advantage (Azih, 2011). As at 1961, Nigeria was the leading exporter of groundnut with a world's share of $42 \%$. The country also had $27 \%$ of the world's palm oil export, $18 \%$ of cocoa and $1.4 \%$ of cotton as the major West African cotton exporter. Up to the early 1970s, agriculture accounted for well over 80 percent of Nigeria's Gross Domestic Product (GDP) and the major value of the country's exports (Oluigbo, 2012). Regrettably, the discovery of crude oil in the late 1960s and the huge financial gains benefitted from it made the government to shift its priority from agriculture to crude oil and relied on food importation as a means of feeding her citizens. The "glory" of agriculture however declined over the years hence Nigeria dominance in the export of groundnut was eclipsed by China, United States of America (USA) and Argentina as at 2008. Indonesia and Malaysia took over in palm oil; Cote d'voire and Ghana also become the leading exporter of cocoa while Mali and Bukina Faso led cotton exports (Azih, 2011). Consequently, Nigeria is currently one of the largest importers of food in the world, spending over $\$ 10$ billion annually importing wheat, rice, sugar and fish (Fertilizer Suppliers Association of Nigeria (FESPAN), nd). Petroleum thus became the pivot around which the nation's economy revolved such that today, any quake in that sector has adverse negative effects on the whole economy.

Concerned about her sole dependence on crude oil for its foreign exchange and food importation as a means of achieving food security, the Nigerian government has made several forays at policies for the development of her agricultural sector. Precisely, since 1980, several interventions, policies and programmes have been executed by different governments aimed at redirecting Nigerians to the farms. Examples include the River Basin Development Programme (RBDP), Operation Feed the Nation (OFN), Green Revolution (GR), the Directorate for Food, Roads and Rural Infrastructure (DFRRI), Agricultural Development Programme (ADP). Notwithstanding these interventions, import bills of Nigeria kept soaring such that she imports approximately US $\$ 3.5$ billion in food products annually making food imports to grow at an unsustainable rate of $11 \%$ per annum (www.doreopartners.com).

Agriculture as an important sector of the economy has high potentials for employment generation, food security and poverty reduction. Unfortunately, these potentials have remained largely untapped notwithstanding the numerous programmes/policies of the past governments (Federal Government of Nigeria (FGN), 2008). The incumbent government has embarked on Agricultural Transformation Agenda (ATA) as part of the Federal Government effort to revamp the agriculture sector to ensure food security, job creation, diversify the economy and enhance foreign exchange earnings. The pertinent questions therefore are: what is the content of ATA that will make it succeed more than the other programmes of the past? What is the role of extension towards achieving the ATA? What are the major challenges extension will face in the ATA journey and how can extension be restructured to fit into the transformation agenda? The paper therefore aims to:

1) discuss the content of the ATA

2) outline the challenges extension will face in the ATA

3) discuss how extension could best be restructured to be relevant in the ATA

\section{METHODOLOGY}

The paper was based on a desk review of available literature. Information was accessed mainly through web search and journals.

\section{The content of the ATA}

ATA is the brainchild of the Federal Ministry of Agriculture and Rural Development aimed at tackling unemployment, creating wealth through the creation of at least 3.5 million agricultural jobs and ultimately achieving food security in Nigeria. The initiative is aimed at an overall development of the agricultural sector with focus on value chain development as a blueprint towards reviving agriculture to its former glory.
The transformation agenda is aimed at making agriculture work for Nigerians especially rural farmers such that it becomes not just a development programme but also an income generating commercial activity. The basic components of the transformation agenda is the development of value chain in selected key crops that have comparative advantage (rice, cassava, sorghum, cocoa and cotton) including the provision and availability of improved inputs (seed and fertilizer), increased productivity and production, as well as the establishment of staple crop processing zones. It is expected to address reduction in postharvest losses, improving linkages with industries as well as access to financial services and markets.

\section{Value chain}

\section{Goals}


Commodity value chain encompasses the whole lot of activities from production, processing distribution and marketing of specific traded commodity and identifies the main stakeholders involved at each stage, including research and development. The concept of value addition is a vital component of the overall strategy for addressing global market competition, post-harvest losses and food security. The main difference between value chain approach and traditional approaches is that the traditional approaches often had a tendency to strengthen the supply capacity of producers and small companies without having a confirmed order, i.e. they assumed that a market would be available, which sometimes was the case and often not.

The value chain approach starts from an understanding of the final demand and works its way back through distribution channels to the different stages of production and manufacturing. This is the major challenge. In a situation where most of the supporting institutions and actors only know how to "push" rather than "pull" then the ended result can easily be predicted, the "chain" will remain stocked in one place. It is equally important to note that the value chain promotion process is knowledge based and demanding, its success depends on the quantum and rate of generation and dissemination of appropriate information and knowledge on challenges, problems and opportunities facing major actors and service providers in the selected value chain, access to inputs, strengthening the delivery of business and financial services, enabling the flow of information, facilitating improved linkages between actors and to higher-value markets. All these activities are potential sources of income generation and employment creation for both skilled and unskilled labour. That is what makes the value chain approach different from other approaches and enhances its attractiveness to development practitioners. However, it is important to note that the value chain approach is a "demand driven" approach popularly referred to as "market driven" approaches. It is different from the traditional "supply push" approach whose emphasis is production oriented. Under the traditional approach producers are encouraged and supported to improve productivity through the use of improved seeds and husbandry practices. The Nigerian agricultural sector evolved over the years to perform this function. This implies that the institutional settings and basic trainings and knowledge of majority of the work force are strategically structured to perform traditional function. There is therefore the need for massive re-orientation and capacity building of major actors, facilitators, supporters and promoters to have a better understanding of the approach as the campaign progresses.

\section{Value chain for key crops that have comparative advantage (cassava, rice, cotton, sorghum and cocoa).}

The transformation agenda sets out to create over 3.5 million jobs from the rice, cassava, sorghum, cocoa and cotton value chains. Other components include self-sufficiency in food and raw material production which will be achieved by curtailing the importation of home-grown crops like rice, wheat and sugar for which Nigeria spent a total of over N1 trillion in the year 2010 alone (Obasi, 2012). Cassava transformation is geared towards the achievement of $20 \%$ of cassava flour in wheat for bread making, noodles and other flour based products thereby stimulating increased production of cassava by 17 million tonnes. The goal of the rice value chain is to achieve self-sufficiency in rice production and ban importation by 2015 . The government has promised to improve rice production by 2 million tonnes. Job creation in rice production is expected to be through primary production, plantation establishment and value chain with an estimated 1Million jobs to be created by 2015. At present, Nigeria is yet to release a BT Cotton (improved) variety that has revolutionized cotton production across the globe. These cotton varieties are however critical to attaining rapid productivity growth in the cotton sector. The current goal is to fast track the release of BT Cotton in Nigeria enabling farmers to double or triple their yields in a short period of time, where cotton yield is expected to increase from $3,000 \mathrm{MMT}$ in 2011 to $7,000 \mathrm{MT}$ by 2015 . It is estimated that 7,000 employment generated across cotton value chain will incline to 22,000 by 2015 . Supply target for Sorghum Component of Fortified Foods for HGSF Program is estimated at $56,000 \mathrm{MT}$ by end of 2012 , with $500 \%$ increase in the volume by 2015 . Similarly, projected supply of Sorghum Component of Fortified Foods for WFP would increase from 29,000MT by end of 2012 to $58,000 \mathrm{MT}$ by 2015 . As at now, 90,000 jobs are being created in primary production of sorghum and 18,000 across the value chain. Cocoa transformation produced 250,000MT of cocoa beans in 2011. The projection however is to double cocoa beans production by 2015 through increased productivity and expansion of cocoa farm. Targeted employment in cocoa primary production is expected to increase from 208,000 in 2012 to 333,000 by 2015 .

\section{Value chain for extension.}

The Federal Government, apart from setting up value chains for major commodities, also established value chain for extension. Value chain for extension is targeted to put in place a legislated, multi-plural, responsive and market-oriented extension system with: assured and regular sources of funding, a welltrained and motivated staff, effectively catering for a variety of actors along targeted value chains of interest to the government.

\section{Leadership}

The Federal Government of Nigeria (FGN) has to partner with relevant privately owned agencies with undiluted zeal and passion for agricultural sector's growth in the implementation of the nations' 
agricultural sector. The transformation of the sector is to be executed through the Agricultural Transformation Implementation Council (ATIC) with President/Vice President at the apex and FMARD at the centre stage for coordination. Leading entrepreneurs such Aliko Dangote and former President Olusegun Obasanjo, owners of some of the largest agricultural enterprises in the country; Kanayo Nwanze, president of the International Fund for Agricultural Development (IFAD); and American economist and Columbia professor, Jeffrey Sachs, are also members of this Council (Federal Ministry of Agriculture and Rural Development, 2011). The council is kicking off the project by identifying key stakeholders in the public and private sectors as well as the agricultural civil society and mapping out areas of collaboration with all key partners in order to maximise impact in the expansion of these value chains. Agricultural Industry Advisory Group (AIAG) and Agricultural Transformation Policy Group (ATPG) determine and institutionalize policy support to the agricultural transformation agenda. The groups represent the voice of the private sector. They are the leading minds in the Nigerian agricultural industry which includes farmers, agricultural input suppliers and manufacturers, agricultural service providers, financial service sector, agricultural processing and trading organizations (Federal Ministry of Agriculture and Rural Development (2011). There are three (3) included implementation groups namely: Agricultural Investment Transformation Implementation Group (AITEG), Agricultural Value Chain Transformation Implementation Group (AVCTEG) and Nigeria Incentive-Based Risk Sharing for Agricultural Lending Implementation Group (NIRSALEG). AITEG is where heads of key MDA's work together to create a conducive environment to grow private sector and public sector investment along strategic value chains. Examples of key MAD's include Finance, Power, Trade and Investment, Water, Works etc. Thus, the existence private sector is strengthened through this group. AVCTEG has the primary function of increasing agricultural productivity and links to markets. NIRSALEG is the group that executes partnership between Central Bank of Nigeria (CBN) and Ministry of Agriculture to unlock $\$ 3$ Billion in agricultural financing.

\section{Financing}

To address the issue of financing the sector, the Central Bank of Nigeria (CBN) in 2010 engaged the Alliance for Green Revolution in Africa (AGRA) to develop the Nigeria Incentive-Based Risk Sharing for Agricultural Lending (NIRSAL) which was launched in 2011. NIRSAL is a new innovative mechanism targeted at de-risk lending to agricultural sector. It is a demand-driven credit scheme put in place given the need for an agricultural financing strategy that would boost output, increase farmers' income, create jobs and provide wealth opportunities across the value chain. The whole essence of the NIRSAL is to spark an agricultural industrialization process through increased production and processing of the greater part of the commodities produced in the country to boost wealth generation across the value chain.

NIRSAL is a N450 billion special credit portfolio set aside by the CBN as its own contribution to the Agricultural Transformation Agenda of the Federal Government. NIRSAL's primary goal is to increase agricultural lending by USD3 billion within 10 years. The successful implementation of NIRSAL had the potential to additionally generate not less than N464 billion of bank lending within a period of 10 years and increase agricultural lending from the current $1.4 \%$ to $7 \%$ total bank lending.

All the commercial banks operating in the country constitute lending channels through which NIRSAL's fund would be disbursed to beneficiaries in a risk sharing manner with the CBN (Ojo, 2012). NIRSAL is a new, dynamic, holistic approach that tackles together both the agricultural value chains and the agricultural financing value chain. The agriculture value chains and the agricultural financing value chain are interdependent.

In moving agricultural financing forward in Nigeria, fixing the financing value chain without addressing the agricultural value chains would be a futile exercise. NIRSAL therefore breaks with tradition by doing two things at once: a) fixes the agricultural value chains, so that banks can lend with confidence into cohesive and complete value chains; and b) encourages banks to lend into the agricultural value chains by offering them strong incentives and technical assistance. NIRSAL is however based on five pillars that aim to "de-risk" agricultural lending and lower the cost of lending for banks. USD 500 million is divided across the five pillars.

\section{Challenges extension will encounter in the on- going ATA}

\section{a) Absence of well-defined agricultural extension policy}

Policy is defined as a form of directed action which indicates as clearly as possible what one wants to achieve, how one wants to do it, and how much time will be taken to achieve the set goals (Adebayo, Babu and Rhoe, 2009). The crucial importance of a well thought out policy to the effectiveness of an extension programme has been well documented (Naswem, Daudu and Ejembi 2008). Countries that have enacted extension policy through legislative action tend to have well-organized, financially stable extension systems that have sustained effectiveness and cumulative impact.

The absence of well-defined agricultural extension policy that outlines the guiding principles for service delivery will be a major problem to the success of extension programme in Nigeria.

\section{b) Poor staffing}

Inadequate staffing of extension staff vis-à-vis geographical coverage and farming population is one of the problems extension will encounter as she tries to be relevant in the on- going ATA. Currently, there is 
wide extension agent (EA)-farm family ratio of 1: EA to approximately between 2,500-10,000 farm families depending on the State (The Extension Transformation Group (TETG), 2011). For the on-going ATA, TETG, 2011 is advocating for proper staffing of 1 EA to 350 farm families.

\section{c) Poor funding}

Grossly inadequate, irregular and untimely release of funds to the agricultural and rural development sector and worse for agricultural extension and advisory services is a big problem to extension service in Nigeria (Auta and Dafwang 2010). Agbamu, (2005); Koyenikan, (2008) stressed the issues of poor funding in extension. Furthermore, in the study conducted by Auta and Dafwang (2010), they noted that the number of extension workers had been reduced drastically due to various reasons. Notable among them was poor funding, which had resulted in retrenchment of staff. They also noted that the problem of funding has also resulted to reduced extension activities, and that in turn has pushed some staff to voluntarily leave the ADPs for greener pastures. Poor funding in addition to other factors, has led to the ADPs' inability to meet their required logistics and manpower development needs. It has also resulted in the widespread problems of low extension-farmer ratio (Auta and Dafwang, 2010). However, cost sharing by the 3 tiers of government, support from development partners, the private sector, NGOs and farmers organizations could be used as a strategy for combating the problem of poor funding in extension (Koyenikan, 2008).

\section{d) Weak Research-Extension-Farmer- Inputs Linkage System (REFILS)}

The Research-Extension-Farmer-Inputs Linkage System (REFILS) is the platform that brings all the actors (both public and private sector) together in the technology development, adaptation, dissemination and utilization process with clearly defined roles and responsibilities for all the actors. The REFILS as designed is expected to bring all the key stakeholders in the agricultural sector together in participatory technology development, adaptation, dissemination and utilization for sustainable agricultural development. It is through REFILS that the state extension services are linked to research institutions on a regular basis. It is the channel by which improved technology is sourced and farmers reactions to new technologies are harnessed as feedback to research institutes to enhance appropriate technology development.

REFILS has however remained weak, uncoordinated and poorly funded and with low participation by the private sector (TETG, 2011). In the on-going ATA, REFILS need to be properly funded so that it will carry out all her activities as at when due, to ensure the development of useful, relevant and appropriate technologies and their effective dissemination to meet the needs/opportunities and challenges of all the actors on the targeted value chains.

\section{Restructuring extension service}

For agricultural extension and advisory services to be relevant in the on-going agricultural transformation agenda, it must be ready to meet the extension needs of all actors along the targeted commodity value chains. This could be achieved by restructuring extension services. According to The Extension Transformation Group (TETG), (2011), extension could be restructured through the following:

\section{(a) Review of the agricultural extension policies within the subsisting agricultural policies}

The first documented but not legislated National Policy on Agriculture was adopted in 1988 at the height of the State-wide ADP era. The Policy provided for adequate food; supply of agricultural raw materials; creating employment; foreign exchange earnings through exports and market for industrial goods (FMARD, 2011) but hardly addressed the challenges of agricultural extension. The 2001 Agricultural policy was perhaps the first to address the issues of public agricultural extension service in Nigeria with particular reference to the roles and responsibilities of the various tiers of government and the private sector. Even though this particular policy document addressed quite adequately the roles of the private sector on agricultural development, including: support for research in all aspects of agriculture, it did not assign any extension role/responsibility. Even with this policy in place, none of the three tiers of government has had the commitment and the will power to date, to implement the tenets of the document with respect to the financing and provision of an effective and efficient agricultural extension service in Nigeria (Arokoyo, 2009). The 2008 Agricultural Extension Policy is the most recent and most authoritative agricultural extension policy pronouncement by government by way of the National Food Security Program document which provided for the establishment of "One-stop" Agricultural Extension Services. It stressed that the agricultural extension service will be professionalized by the state governments establishing farm support centres as "one-stop" facilities in each local government in partnership with the private sector to train and teach new farming techniques" Further, the program will train 10,000 highly competent extension workers per year with the objective of achieving a ratio of at most of 1:350 Extension Agent/Farm family ratio. This pronouncement is a typical government's topdown planning process with no consultation with the states and Local Governments and the private sector. Field surveys make the proposed ratio of 1:350 totally unrealistic in the immediate future in Nigeria considering the current situation on the ground (1: EA to approximately between 2,500-10,000 farm families depending on the state (Arokoyo, 2009). A major worry of the policy was that modalities of implementation have neither been clearly spelt out nor subjected to wide consultations among the potential key stakeholders. The policy however died a natural death 
with the termination of the last administration that initiated it. Generally, the problems with these policies include lack of legal framework for extension activities, policy without practice, lack of leadership/coordination and non-involvement of the key actors and development partners in policy articulation (e.g is the 'one stop' of the 2008 Agricultural Extension Policy). Hence, the need for the review of the agricultural extension policies within the subsisting agricultural policies and recommend appropriate policies that will ensure legal framework for extension services, the effective participation of all stakeholders in a stable policy environment and adequate funding for the delivery of efficient and effective agricultural extension and advisory services cannot be overemphasized.

\section{(b) Capacity building for extension personnel}

The value chain approach adopted for the implementation of the transformation agenda demands a higher level of skills and knowledge by the drivers (ADP staff i.e. extension agents). Consequently, the staff must benefit from a robust capacity building programme in order to be able to deliver. The ADPs had the best capacity building programme during the era of the World Bank support with each ADP then having a Manpower Development and Training Department/ Component, they delivered then . However, with the closure of the World Bank loan assistance the component crumbled like some many others in the ADP system and has virtually remained so since. Unfortunately, most of the recent trainings offered to the ADPS have been supply-driven rather than demand-driven and so have made only minimal impact in the field. A robust Manpower Development and Training Program for the ADPs - the arrowhead of the public extension service, is critical for the success of not only the extension transformation agenda but for the entire agricultural transformation agenda of the government (TETG, 2011). The capacity building program must be demand-driven and comprise of both on-site and off - site extension communication, technical, leadership and managerial courses. To achieve capacity building, the universities and the Agricultural and Rural Management Training Institute (ARMTI), should collaborate with other relevant organizations and individual experts to immediately carry out training needs assessment of all the ADPs nation-wide, this will be part of the resuscitation of the ADPS. ARMTI and National Agricultural Extension and Research Liaison Service (NAERLS) along with any other Manpower Development Institutions that have the expertise to provide capacity building for staff of the ADPs in Commodity Value Chain Promotion and Development should be mandated to conduct capacity building in this area for both the ADP staff and all the actors in the selected commodity value chains. ADPs should "bring back" the Manpower Development and Training Units to effectively sustain the prosecution of the agricultural transformation agenda.

(d) Adequate commitment by the Federal government to the newly established Federal Department of Agricultural Extension (FDAE) in the

\section{Federal Ministry of Agriculture and Rural Development}

TETG (2011) recommended the creation of Federal Department of Agricultural Extension (FDAE) within the Federal Ministry of Agriculture and Rural Development. Very recently the Department was created. The FDAE is expected to provide the critically needed leadership, coordination, quality control and assurance and the overall effective and efficient delivery of all agricultural extension and advisory services in Nigeria. The FDAE will also ensure the harmonization of public, private and externally funded projects to ensure optimum management of scarce resources. The structural organization of the Department will be headed by a Director and will have six (6) Divisions, each headed by a Deputy Director. The Divisions will include: i) Field Extension Services Division ii) Women, Vulnerable Groups and Youths Division iii) Planning, Monitoring and Evaluation (PME) Division iv) Media and Communications Division v) Value Chain Promotion and Development Division vi) Capacity Building Division. This Department will be similar to those of Federal Agricultural Coordinating Unit (FACU) and Agricultural Projects Monitoring and Evaluation Unit (APMEU) which coordinated the ADPs, monitored and evaluated their performance and provided management information service under the World Bank support for integrated agricultural development in Nigeria (TETG, 2011). The government will ensure that all necessary support be provided to the FDAE to enable her achieve the anticipated success. The government should not allow the FDAE to just exist but be truly committed to making her functional and effective.

\section{(e) Proper funding and staffing of extension service}

Funding of agricultural extension service in Nigeria poses a serious challenge. As a matter of fact, the extension service in the country collapsed after the expiration of World Bank loans due primarily to poor funding (TETG, 2011). The counterpart contributions by federal and state governments which formed part of the loan covenants were jettisoned once the loan agreements expired. Consequently, the ADPs became starved of funds and thus were unable to effectively perform their statutory function of extension delivery. Nigeria should learn from the experience of the United States of America as a Federal polity and legislate an Agricultural Extension Policy which guarantees cooperation, collaboration and financial support by the three tiers of government - Federal, State and Local Government (County in the case of the USA) to the extension service. In the USA, the Federal Government contributes 43 percent, States 39 percent and Counties 18 percent to the financing of the Cooperative Extension Service under the Smith-Lever Act of 1914. In Nigeria, tripartite funding of extension by all the three tiers of government should be 
encouraged, the sharing formula could be in the order in which the Federation Account is allocated. Other options could include the establishment of a dedicated tax fund; say 5 percent derivable from agricultural imports into the country (TETG, 2011). Adequate funding of extension could help achieve the dream of proper staffing of extension agent/farmer ratio of 1 : 350.

\section{CONCLUSION AND RECOMMENDATION}

ATA is aimed at tackling unemployment, creating wealth through the creation of at least 3.5 million agricultural jobs and ultimately achieving food security in Nigeria. The role of extension toward achieving the ATA cannot be overemphasized. Unfortunately, the Nigerian extension service is bedeviled by several problems ranging from absence of well-defined agricultural extension policy to poor funding. To make extension relevant in the on-going ATA, the paper recommends that extension should be properly funded by the three tiers of government in Nigeria. Furthermore, the federal government should be committed in supporting the newly established Federal Department of Agricultural Extension (FDAE).

\section{REFERENCE}

Adebayo, K, Babu, S and Rhoe, V. (2009). Institutional capacity for designing and implementing agricultural and rural development policies and strategies in Nigeria. Background Paper No. 008. Nigeria Strategy Support Program (NSSP) of the International Food Policy Research Institute (IFPRI).

Agbamu, J. U. (2005). Problem and prospects of agricultural extension service in developing countries. In: S. F. Afolayan (Ed) Agricultural Extension in Nigeria. Ilorin AESON, 159-169.
Arokoyo, T (2009). An effective and functional extension service to maximize farmers' productivity. An invited paper presented at the National Conference on Agricultural Finance and the Role of Communication in Sustainable Development in Nigeria, Organized by PR Value Consulting, Murtala Muhamad Library Complex, Kano, Sept. $29^{\text {th }}-30^{\text {th }}, 2009$.

Auta, S.J. and Dafwang, I.I. (2010). The Agricultural Development Projects (ADPs) in Nigeria: status and policy implications. Research Journal of Agriculture and Biological Sciences. 6(2): 138-143.

Azih, I. (2011). A background analysis of the Nigerian agricultural sector (1998 to 2007) available at http:www.manufacturingnigeria.com/index.php/analysis Federal Government of Nigeria (FGN), (2008). National Food Security Program. Federal Ministry of Agriculture and Water Resources, Abuja, Nigeria. Federal Ministry of Agriculture and Rural Development (FMARD), (2011). Agricultural transformation agenda: we will grow Nigeria's agricultural sector. Draft for Discussion. Fertilizer Suppliers Association of Nigeria (FESPAN), (nd) Newsletter Volume 2 No 5.

Koyenikan, M. J. (2008). Issues for agricultural extension policy in Nigeria. Journal of Agricultural Extension. 12 (2): 52-62.

Naswem, A.A.; Daudu, S. and Ejembi, E.P. (2008). Legislated policy as the basis for effective extension delivery: Lessons from the United Kingdom. Journal of Agricultural Extension. 12 (2)

Obasi, T (2012). Shedding light on the Agricultural Transformation Agenda. Business day Newspaper, 30 ${ }^{\text {th }}$ August, 2012.)

Ojo, B (2012). Nigeria is not ready for private agric extension. Compass Newspaper, $23^{\text {rd }}$ March. Available at http:www/compassnespaper.org).

Oluigbo, C. (2012). Achieving food self sufficiency in Nigeria. Business day Newspaper, 29 $9^{\text {th }}$ Feb 2012. The Extension Transformation Group (TETG), (2011). Final report of the agricultural extension transformation component of the Agricultural Transformation Agenda of the Federal Ministry of Agriculture and Rural Development. Vol. 1: Main Report. www.doreopartners.com

Cite this Article: Obiora CJ and Emodi Al (2013). Restructuring the Agricultural Extension Service for Effective Agricultural
Transformation Agenda in Nigeria. Greener Journal of Agricultural Sciences, $3(6)$ : $511-517$,
http://doi.org/10.15580/GJAS.2013.6.061013660.

